\title{
Influence of martensite particle size on dry sliding wear behaviour of low carbon dual phase powder metallurgy steels
}

\author{
A. Güral* \\ Gazi University, Technical Education Faculty, Materials Science Division, 06500, Teknikokullar, Ankara, Turkey
}

Received 13 March 2009, received in revised form 13 September 2009, accepted 21 October 2009

\begin{abstract}
This study aimed to investigate the effect of martensite particle size on dry sliding wear properties of dual phase PM steels. For this purpose, atomised iron powder with 0.3 wt.\% graphite powder was cold pressed and sintered at $1200^{\circ} \mathrm{C}$. Some of the sintered specimens were annealed at intercritical heat treatment temperature of $750^{\circ} \mathrm{C}$ and water-quenched to obtain coarse martensite region. The others were first austenitized at $890^{\circ} \mathrm{C}$, water-quenched and subsequently re-annealed at intercritical annealing temperature of $750{ }^{\circ} \mathrm{C}$ before rapidly water re-quenching to produce fine martensite size. Wear tests were performed in a pin-on-disc test device under $25 \mathrm{~N}$ load at $125 \mathrm{~m} \mathrm{~min}^{-1}$ sliding speed. The wear rate decreased with decreasing martensite particle size due to the reducing inter-martensite particle spacing, increasing hardness of ferrite phases and decreasing cracking of fine martensite particles.
\end{abstract}

K e y w or d s: powder metallurgy steel, sintering, dual phase steel, martensite particle size, dry sliding wear

\section{Introduction}

Complex and net-shaped parts with precise surface and extensive chemical compositional tolerance can be produced by PM route and their properties can be improved physically and chemically. Adding certain alloying elements to iron powders enhances many properties of ferrous PM parts. Carbon is the most widely used alloying element to enhance strength of PM steels by adding graphite $[1,2]$.

Some previous studies focused on dry sliding wear properties of ferrous PM steels in terms of microstructure, hardness, porosity ratio and alloying elements $[3,4]$. It has been noticed that the wear mechanisms of PM steels are similar to those displayed by ingot materials [5]. However, porosity amounts within PM steels dramatically affect their wear behaviour [3-6].

The wear resistance of low carbon steels can be improved by proportion of hard and tough phases such as tempered martensite or bainite in the microstructure. On the other hand, the martensitic phase with higher hardness may not be beneficial for wear res- istance. Martensite phase can be easily cracked under loads during dry sliding wear and thus the weight loss from the surface is increased. Wang and Danninger [7] found that wear rate of Mo alloyed PM steels in as-sintered state with bainite phase was lower than in a quenched and tempered state. However, when the amount and morphology of martensite phases in the microstructure are controlled, wear properties of steels can be optimised. Therefore, cracking of martensite can be reduced by the presence of softer phases like ferrite. Martensite volume fraction and morphology can be controlled by intercritical annealing heat treatments. The aim of intercritical annealing heat treatment is to produce ferrite plus martensite in the microstructure of low carbon steels [8-10]. These heat treatments are applied by heating low carbon steels between the $A_{\mathrm{c} 1}-A_{\mathrm{c} 3}$ temperatures forming austenite plus ferrite regions followed by a rapid cooling to get the transformation of austenite to martensite. Intercritical annealing temperatures determine martensite volume fraction. Austenite (after quenching martensite) volume fraction increases with increasing inter-

\footnotetext{
* Tel.: +90 312 2804376; fax: +90 312 2120059; e-mail address: agural@gazi.edu.tr
} 
critical annealing temperatures $[8,11]$. The size and morphology of martensite regions are determined by the initial microstructure of the steel before intercritical annealing heat treatment $[9,12,13]$. Coarse ferrite plus martensite microstructure are produced with an initial microstructure of ferrite plus pearlite, whereas homogeneously dispersed fine martensite in the ferrite matrix is produced in specimens with an initially fully martensitic microstructure. Modi [14] found that the wear rate decreased with an increase in the content of hard and strong martensite phase in low carbon dual phase steel when tests were performed using fine abrasive $(13$ and $20 \mu \mathrm{m})$ particles. However, Aksoy et al. $[15]$ indicated that mass loss increases with martensite volume fraction in low carbon dual phase steels. Besides, Bayram and Uğuz [16] informed that dual phase steels with finer and homogeneously dispersed martensite in the ferritic matrix exhibit better wear properties.

In this study, effects of different martensite particle sizes at fixed martensite volume fraction on dry sliding wear properties of PM steel with $0.3 \mathrm{wt} . \%$ graphite were investigated.

\section{Experimental procedure}

Atomised iron (Ancorsteel 1000 Hoeganaes, USA) and natural graphite with flake-like powders were used in the present study. Test specimens were prepared by directly mixing 0.3 wt.\% graphite with the iron powder. $0.5 \mathrm{wt} . \% \mathrm{Zn}$ stearate was added to the powders as lubricant. The mixed powders were cold pressed at $700 \mathrm{MPa}$ by uniaxial compaction and sintered at $1200^{\circ} \mathrm{C}$ for 30 min under pure argon gas atmosphere. The rate of heating to and cooling from the sintering temperature was kept at $5^{\circ} \mathrm{C} \mathrm{min}^{-1}$. Cylindrical pins of $10 \mathrm{~mm}$ diameter and $20 \mathrm{~mm}$ length were prepared for wear test specimens. Heat treatments were carried out in a vertical furnace, which enabled rapid quenching of the test specimens. In order to produce ferrite plus coarse martensite microstructures after sintering, the specimens were directly annealed at intercritical annealing temperature of $750^{\circ} \mathrm{C}$ for $16 \mathrm{~min}$ and water quenched. Specimens with this heat treatment were coded as coarse martensite particle (CMP). To produce fine ferrite plus martensite microstructures, the other sintered specimens were first austenitized at $890^{\circ} \mathrm{C}$ for $12 \mathrm{~min}$ and water-quenched to produce a fully martensitic structure. These fully martensitic specimens were then intercritically annealed at $750^{\circ} \mathrm{C}$ and re-quenched in water. Specimens with these heat treatments were coded as fine martensite particle (FMP). Schematic illustration of the heat treatments applied to the sintered tensile test specimens is given in Fig. 1.

Macrohardness values of each specimen were meas-
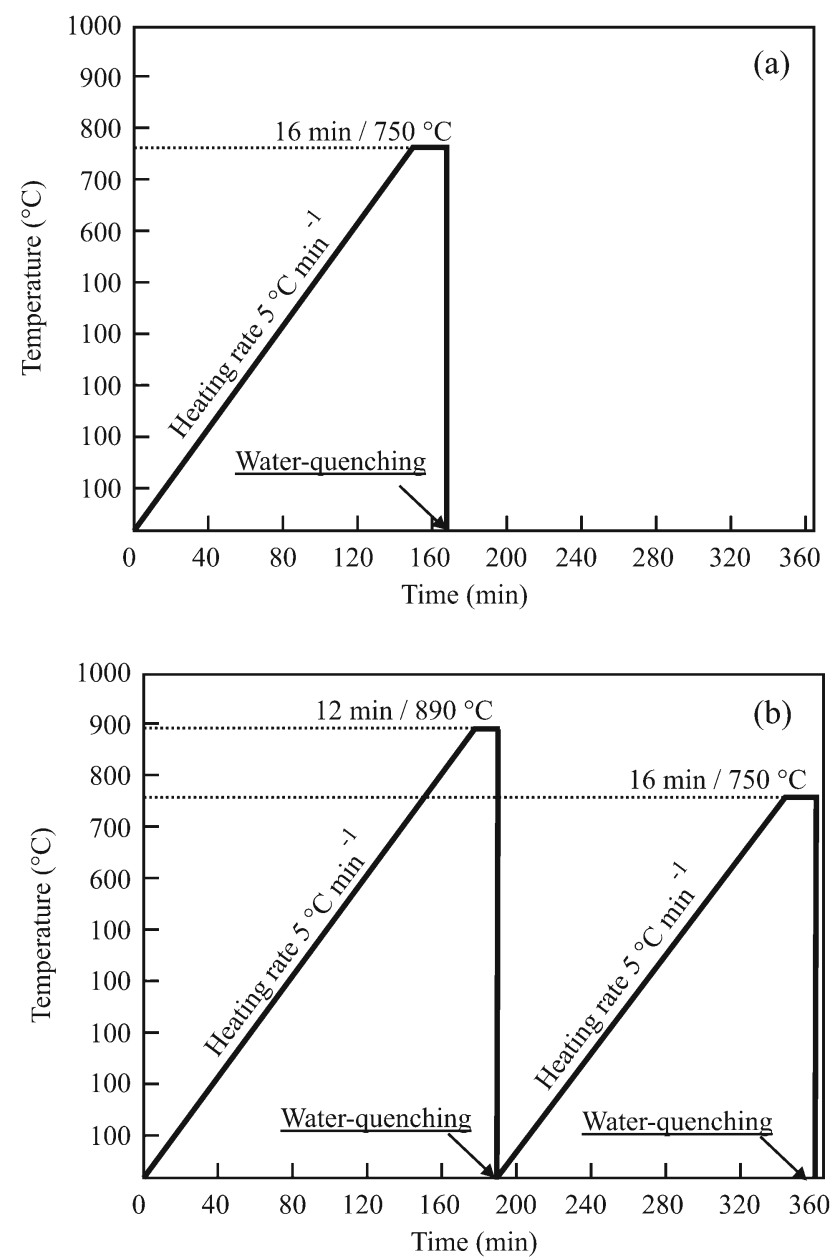

Fig. 1. Schematic heat treatment cycles for (a) CMP and (b) FMP specimens after sintering.

ured with an Instron Wolpert Vickers tester using a $30 \mathrm{~kg}$ load. Microhardness values of the phases in the microstructures were determined with a Shimadzu HMV-2 Vickers tester using a $10 \mathrm{~g}$ load.

For microstructural investigation, specimens were ground and polished by using usual metallographic procedures. $2 \%$ nital etching was used to reveal the microstructures. After etching, the specimens were washed with running water and rinsed with methyl alcohol to remove the etchant from the surfaces. Scanning electron microscope (JSM Jeol 6060) was used to characterize the microstructure of the specimens. The mean linear intercept method was used to determine the size of martensite islands.

The dry sliding wear tests were carried out on a standard pin-on-disc machine with a continuously rotating steel plate with 55 HRc. The friction coefficients of the specimens were measured directly during the test using a load cell. All the tests were carried out at a constant load of $25 \mathrm{~N}$, a sliding speed of $125 \mathrm{~m} \mathrm{~min}^{-1}$ and total sliding distance of $3000 \mathrm{~m}$. The tests were in- 


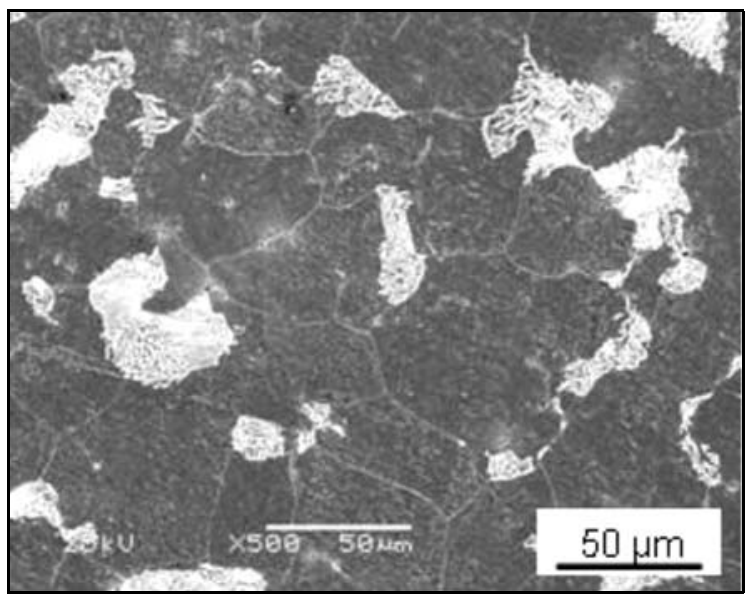

Fig. 2. Ferritic plus pearlitic microstructure of as-sintered material (used for the CMP specimen before intercritical annealing heat treatment).

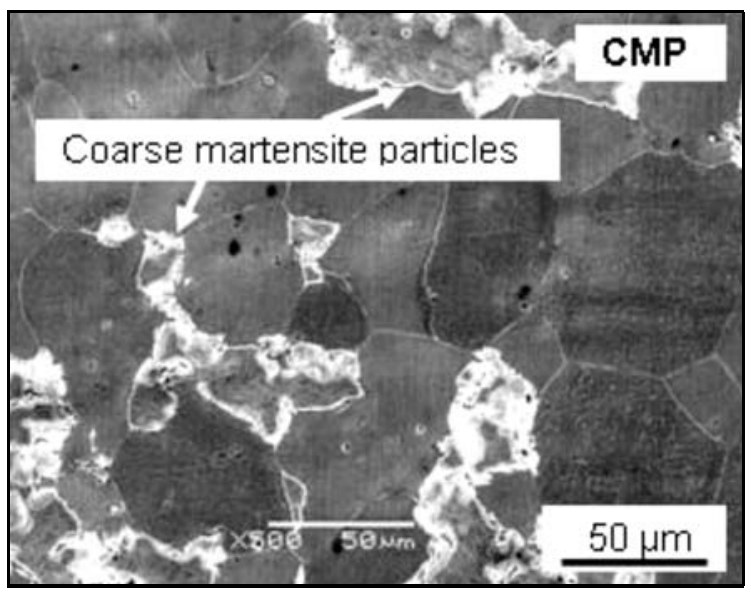

Fig. 3. Microstructure of CMP specimen with coarse martensite particles.

terrupted after running for different sliding distances and the weight loss was measured after careful cleaning of the specimens. The wear rates of specimens were determined by dividing the volume of the worn out specimens by total length of the wear distance. A scanning electron microscope (SEM JSM 6060) was used to characterize the microstructures and worn surfaces of the specimens.

\section{Results and discussion}

\subsection{Microstructure}

The material with ferrite plus pearlite microstructures sintered at $1200^{\circ} \mathrm{C}$ for $30 \mathrm{~min}$ is shown in Fig. 2 . Post-sintering typical lamellar pearlite colonies mostly occurred at the ferrite grain boundaries. The sintered

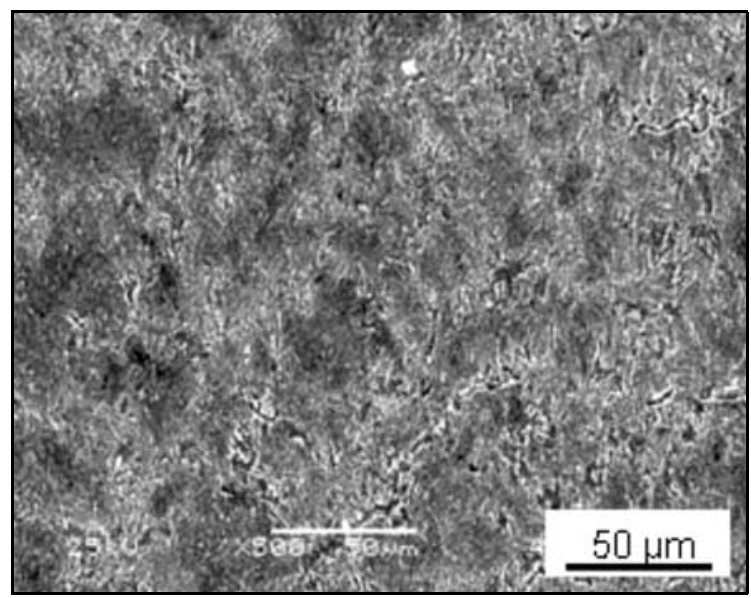

Fig. 4. Fully martensitic microstructure of water-quenched material (used for the FMP specimen before intercritical annealing heat treatment).

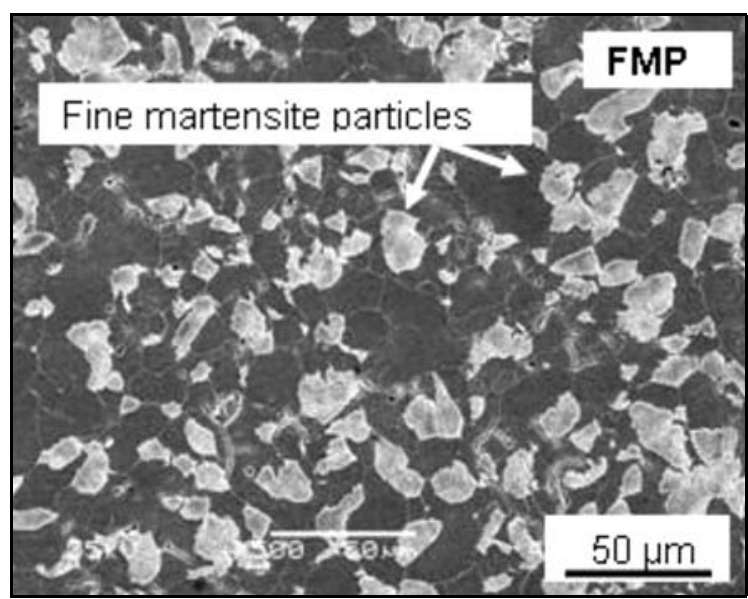

Fig. 5. Microstructure of FMP specimen with fine martensite particles.

material was used as the initial microstructure of the CMP specimens. To produce coarse martensite regions in these specimens, they were intercritically annealed at $750{ }^{\circ} \mathrm{C}$ for $16 \mathrm{~min}$ and then rapidly water-quenched. Austenite formed during the intercritical annealing preferentially at C-rich pearlitic areas and transformed into martensite during quenching. By this heat treatment route, the obtained average martensite particle size was $31 \pm 11 \mu \mathrm{m}$ in the CMP specimens (Fig. 3). In these specimens, martensite particles formed along the grain boundaries of soft ferrite and interconnected with each other as well. Thus, the distribution of coarse martensite particles was inhomogeneous in the microstructure.

Fully martensitic microstructure was first produced by quenching from $890^{\circ} \mathrm{C}$ after sintering (Fig. 4). The initial microstructure of the FMP specimen before intercritical annealing was fully martensite. This 
Table 1. The properties obtained in specimens after heat treatments

\begin{tabular}{ccccccc}
\hline Specimen & $\begin{array}{c}\text { Martensite } \\
\text { volume fraction } \\
(\%)\end{array}$ & $\begin{array}{c}\text { Martensite } \\
\text { particle size } \\
(\mu \mathrm{m})\end{array}$ & $\begin{array}{c}\text { Interparticle distance } \\
\text { of martensite } \\
(\mu \mathrm{m})\end{array}$ & $\begin{array}{c}\text { Macrohardness } \\
\text { HV 30 }\end{array}$ & $\begin{array}{c}\text { HV 0.01 } \\
\text { martensite }\end{array}$ & ferrite \\
\hline CMP & $\sim 35$ & $31 \pm 11$ & $55 \pm 17$ & $203 \pm 6$ & $590 \pm 17$ & $157 \pm 5$ \\
FMP & $\sim 35$ & $9 \pm 3$ & $16 \pm 9$ & $224 \pm 8$ & $588 \pm 5$ & $172 \pm 7$ \\
\hline
\end{tabular}

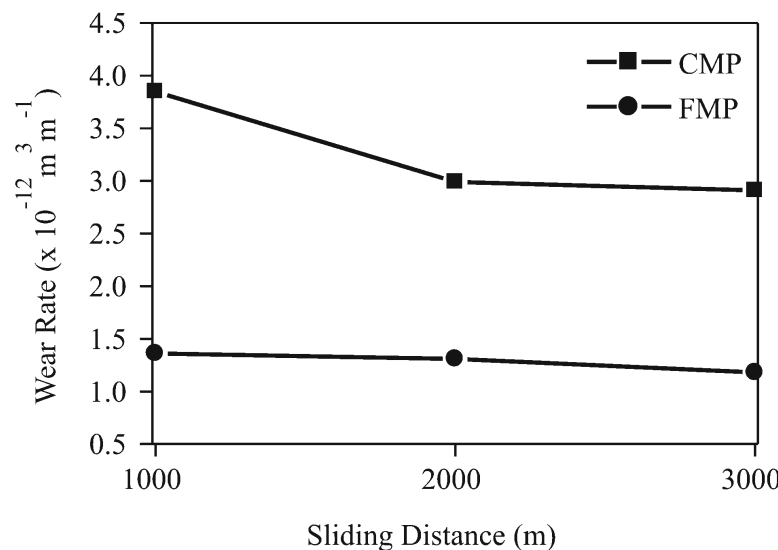

Fig. 6. Variation of wear rate with sliding distance for CMP and FMP specimens.

fully martensitic specimen was then intercritically annealed at $750^{\circ} \mathrm{C}$ and re-quenched in water. Thus, fine equiaxed martensite particles with average $9 \pm 3 \mu \mathrm{m}$ were produced (Fig. 5). Compared to CMP specimens, in FMP specimens, a more uniformed distribution of fine martensite islands was obtained in the soft ferrite matrix.

The martensite volume fraction after quenching from $750{ }^{\circ} \mathrm{C}$ was $\sim 35 \%$ in both the CMP and FMP specimens due to the same intercritical annealing temperature of $750^{\circ} \mathrm{C}$. It is well known that intercritical annealing temperatures control the martensite volume fraction. As it can be seen in Table 1, interparticle distance of the martensites in the CMP specimen is higher than that of the FMP specimen due to the smaller density of coarse martensite particles at the same martensite volume fraction. The macrohardness values of the specimens, as well as the microhardness of martensite and ferrite phases, are given in Table 1. The macrohardness of the FMP specimens is higher than that of the CMP specimen. With regard to the grain size, the strength of dual phase steels is known to obey the Hall-Petch equation [17]. Therefore, the macrohardness of FMP specimens was higher than that of the CMP specimens owing to the fine grains at the same volume fraction.

As can be seen in Table 1, the microhardness values of martensite phases were almost the same in both specimens. This is the result of quenching of the specimens from constant intercritical annealing temperat- ure. However, in the FMP specimens, microhardness values of ferrite around martensite phases were higher than those of the CMP specimens. The microhardness of ferrite phases can be affected by dislocation density in dual phase steels. It is also known that austenite, after transforming into martensite, deforms the surrounding ferrite and forms mobile dislocations [18]. Thus, ferrite phases in the FMP specimens, in which the spacing between martensite particles is shorter, can be expected to be more strain-hardened than those in the CMP specimens.

\subsection{Wear properties}

The variation of the wear rate with sliding distance for the CMP specimen is shown in Fig. 6. The wear rate of the FMP specimen is less than that of the CMP specimen despite the little difference in hardness between these specimens. It was thought that the wear behaviour was significantly affected by the martensite particle size and inter-particle distance of the martensite. The presence of hard phases in microstructures is usually desirable for improved wear resistance and high hardness of martensite phases may reduce the sliding wear coefficient. However, brittleness of martensite phases might be disadvantageous for the dry sliding wear process [4, 19], causing increased mass loss. Repeated contact of the counter surfaces leads to accumulation of strains in the sliding surfaces of specimens during dry sliding wear, which subsequently forms surface deformation layers with increased dislocation density [20]. Wang and Danninger [7] indicated that the wear rate in the as-quenched specimens was higher than that of the as-sintered condition. Wear rate also increased in some dual phase steels with an increase in the martensite volume fraction $[15,21]$. Wear rate could be reduced by lowering the brittleness of dual phase steels with high ferrite volume fraction. Finer grained dual phase steels exhibit higher wear resistance due to their higher toughness than that of coarse-grained dual phase steels with the same chemical composition.

Wear resistance in dual phase steels is offered by the hard martensite phase whereas soft ferrite improves work hardening capability. In the FMP specimen, the size of the martensite particles was less than that in the CMP specimen. Thus, the wear resistance offered by the finer hard martensite colonies 


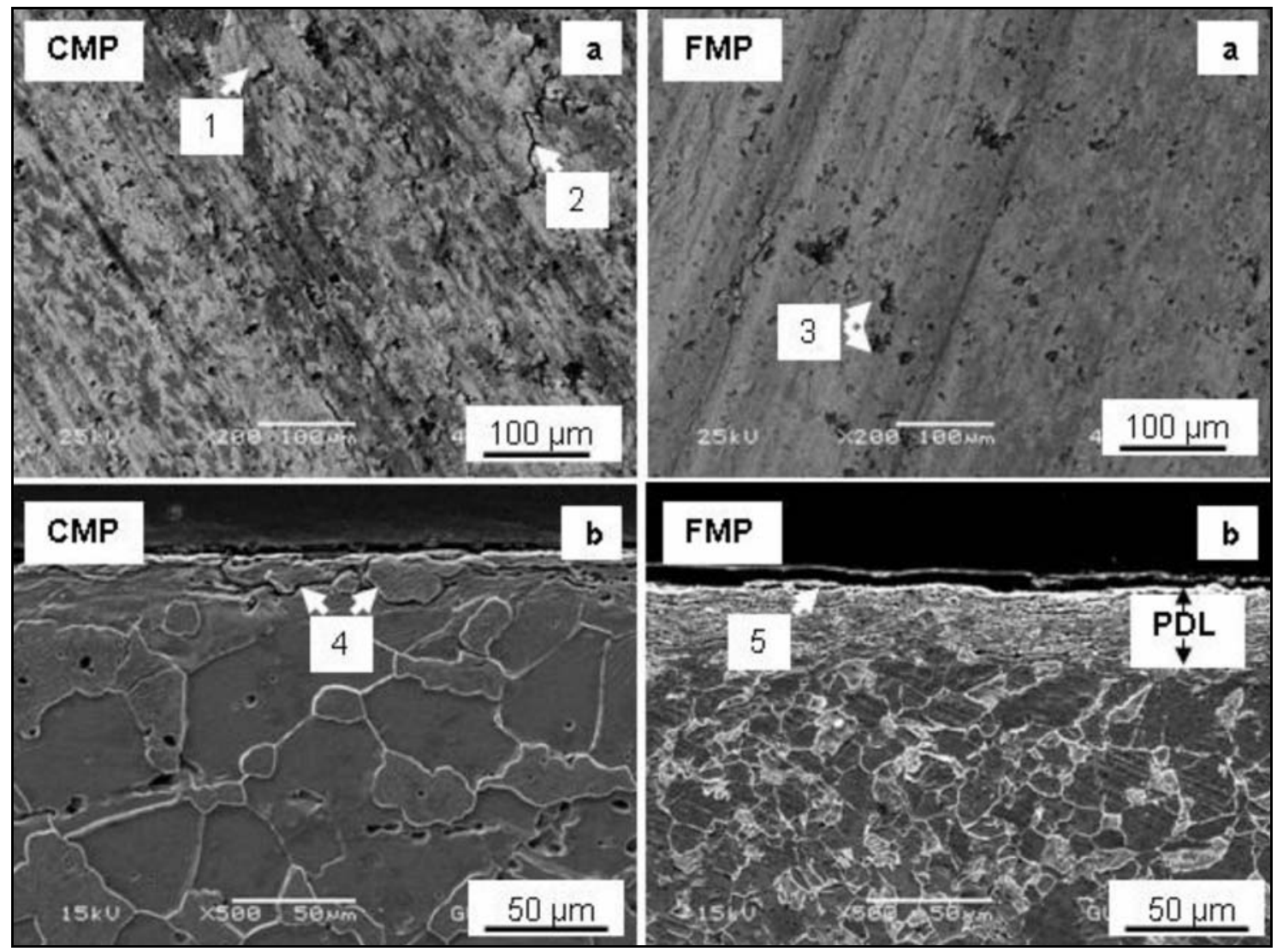

Fig. 7. Worn surfaces (a) and cross-section perpendicular to worn surfaces (b) of CMP and FMP specimens.

was less efficient as compared to the coarser martensitic colonies. The wear rate of the FMP specimen with fine microstructure decreased owing to homogeneously distributed fine martensite in the soft ferrite phase.

When steels having a fully martensitic initial structure are annealed at the intercritical annealing region, as in the FMP specimen, the orientation of a new austenite nucleated at grain boundaries of laths of martensite could be related to both parent grains. After quenching, coherency of fine martensite/ferrite interface is more pronounced than that of coarse martensite/ferrite interface [22]. Thus, it is considered that cracking risk of martensite particles in the FMP specimen could be reduced.

The microhardness of ferrite phases increased in the FMP specimen due to the inter-particle distance of martensites in it, which is approximately three times lower than that of the CMP specimen as can be seen in Table 1. Therefore, it could be related to lower wear rate. More mass loss occurs in steels with hard-brittle martensite, which causes a lower sliding coefficient. The coarse martensites in the CMP specimens suffered more mass loss than those in the FMP specimens. Figure $7 \mathrm{a}$ shows the worn surface of the specimens. Also, the wear micrographs of the samples sectioned perpendicular to the sliding direction can be seen in Fig. 7b. The surface of the CMP specimen scaled off as a result of the dry sliding process. It is seen that in the CMP specimen wear scars are deeper. Adhesive and delaminating wear regimes were observed for the CMP specimen as can be seen in position 1 and 2 in Fig. 7a. These types of wear mechanisms lead to more mass loss. It is seen that the worn surface of FMP specimens is smoother than that of the CMP specimens. Craters on the surface of the FMP specimen were of small size $(\sim 5-10 \mu \mathrm{m})$ (position 3 in Fig. 7a). Undoubtedly, in the FMP specimen, mass loss in these small size craters was far less in comparison to delaminating and adhesive mechanisms in the CMP specimen.

As can be seen in the cross-section of the worn CMP specimen, subsurface cracks resulting in mass loss occurred especially in the coarse martensite/ferrite interface (position 4 in Fig. 7b). It is assumed that fragmented martensite particles, which remained between the disc and the specimen during dry sliding wear test, might have caused deeper wear tracks. In the cross-section of worn FMP specimen, on the other hand, it was observed that the thin layer at the surface cracked. This might have been a result of the damage by plastic deformation (position 5 in Fig. 7b). It is noticed that the plastic deformation layer (PDL) on the surface of the FMP specimen is much thicker than that of the CMP specimen. A significant plastic deforma- 


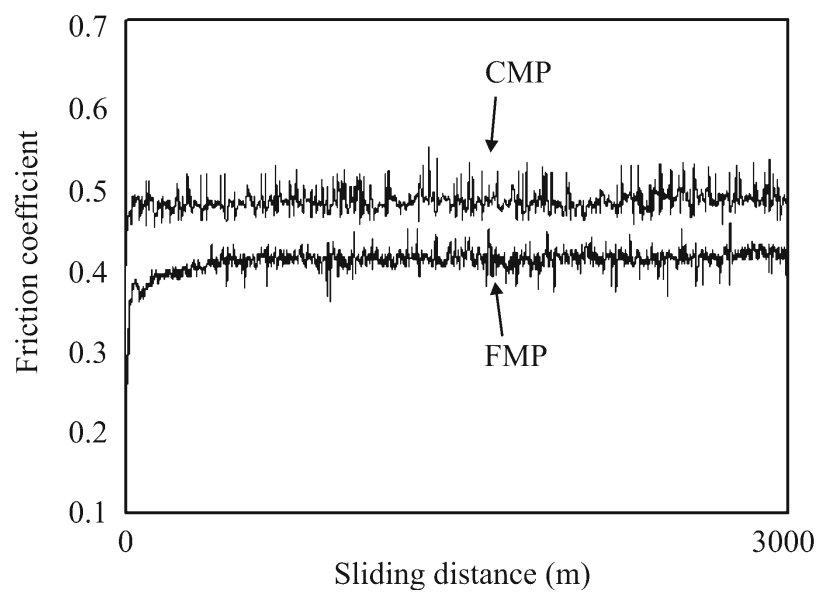

Fig. 8. Variation of the friction coefficient with sliding distance of CMP and FMP specimens.

tion capacity is a general characteristic of dual phase steels with fine martensite particle dispersion [11, 23]. Also, it can be seen in Fig. 7b that martensite phases significantly deformed plastically in the FMP specimen. Therefore, less martensite cracking occurred in the FMP specimens. Two possible explanations might be suggested for this. The first possibility is that, as it has been mentioned earlier, stress transferred from ferrite to martensite might have been better transmitted due to martensite's better coherency with the surrounding ferrite than in specimens which went through similar heat treatments in previous studies [22]. The second, and the stronger, possibility is that martensite was dynamically tempered and the plastic deformation was easier. In this study, it was found that the microhardness of the martensites near the PDL of the FMP specimens decreased to $507 \pm 9 \mathrm{HV}$ from $588 \pm 6 \mathrm{HV}$ after the wear test.

Figure 8 shows the friction coefficient curves of the specimens. The initial friction coefficient at the beginning of the dry sliding wear test varies between 0.2 and 0.4 for the CMP and the FMP specimens, respectively. After approximately $100 \mathrm{~m}$ of sliding distance, the friction coefficients raised about 0.37 and 0.48 for the CMP and FMP specimens, respectively. The curves are irregular owing to both abrasion and adhesion phenomena. The average friction coefficient decreased with decreasing martensite particle size and the increasing hardness of the FMP specimen at the same martensite volume fraction. It is known that steels with martensite phases provide lower friction coefficient. However, heterogeneity of coarse martensite dispersion and lower hardness of ferrite phases raised the friction coefficient for the CMP specimen.

\section{Conclusions}

Effects of different martensite particle size at fixed martensite volume fraction on dry sliding wear properties of PM steels with 0.3 wt.\% graphite were investigated. The results are as follows:

1 . The wear rate of the specimen with fine martensite particle size (FMP) was less than that of the specimen with coarse martensite particle size (CMP) despite the little difference in hardness of these specimens. It was thought that the wear behaviour was significantly affected by martensite particle size and inter-particle distance of martensite. The wear rate of the FMP specimen with a fine microstructure is smaller than that of CMP owing to homogeneously distributed fine martensite in the soft ferrite phase.

2. The microhardness of the FMP specimen is higher due to the fact that inter-particle size of martensites in the FMP specimen is approximately three times smaller than that of the CMP specimen. Thus, it could yield lower wear rate.

3 . The worn surface of the CMP specimen scaled off as a result of the dry sliding process. Also, it was seen that wear scars in the CMP specimen were deeper. Adhesive and delaminating wear regimes were observed for the CMP specimen. In the FMP specimen mass loss in small size craters was far less in comparison to delaminating and adhesive mechanisms in the CMP specimen. Subsurface cracks occurred especially in the coarse martensite/ferrite interface in the worn surface of the CMP specimen. These cracks resulted in significant mass loss of larger martensite particles.

4. The average friction coefficient decreased with decreasing martensite particle size and the increasing hardness of ferrite phases for the FMP specimen at the same martensite volume fraction.

\section{References}

[1] NARASIMHAN, K. S.: Mater. Chem. Phys., 67, 2001, p. 56.

[2] DANNINGER, H.-GIERL, C.: Mater. Chem. Phys., 67, 2001, p. 49.

[3] SIMCHI, A.-DANNINGER, H.: Powder Metall., 47, 2004, p. 73.

[4] ANTÓN, N.-DELGADO, J. L.-VELASCO, F.TORRALBA, J. M.: J. Mater. Process. Tech., 143144, 2003, p. 475 .

[5] YOUSEFFI, M.-WRIGHT, C. S.-JEYACHEYA, F. M.: Powder Metall., 45, 2002, p. 53.

[6] CESCHINI, L.-PALOMBARINI, G.-SAMBOGNA, G.-FIRRAO, D.-SCAVINO, G.-UBERTALLI, G.: Tribol. Int., 39, 2006, p. 748.

[7] WANG, J.-DANNINGER, H.: Wear, 222, 1998, p. 49.

[8] TAVARES, S. S. M.-PEDROZA, P. D.-TEODÓSIO, J. R.-GUROVA, T.: Scripta Mater., 40, 1999, p. 887.

[9] KIM, K. J.-LEE, C. G.-LEE, S.: Scripta Mater., 38,1997, p. 27.

[10] GÜRAL, A.-BOSTAN, B.-ÖZDEMIR, A. T.: Mater. Design, 28, 2007, p. 897. 
[11] GÜRAL, A.-TEKELI, S.-ANDO, T.: J. Mater. Sci., 41, 2006, p. 7894.

[12] MONDAL, D. K.-DEY, R. M.: Mater. Sci. Eng. A, 149, 1992, p. 173.

[13] SARVAR, M.-PRIESTNER, R.: J. Mater. Sci., 31, 1996, p. 2091.

[14] MODI, A. P.: Tribol. Int., 40, 2007, p. 490.

[15] AKSOY, M.-KARAMIŞ, M. B.-EVIN, E.: Wear, 193, 1996, p. 248.

[16] BAYRAM, A.-UĞUZ, A.: Materialwiss. Werkst., 32, 2001, p. 249.

[17] CHANG, P. H.-PREBAN, A. G.: Acta Metall., 33, 1985, p. 897.
[18] EL-SESY, I. A.-EL-BARADIE, Z. M.: Mater. Lett., 57,2002 , p. 580 .

[19] COLAÇO, R.-GORDO, E.-RUIZ-NAVAS, E. M.OTASEVIC, M.-VILAR, R.: Wear, 260, 2006, p. 949.

[20] SUDHAKAR, K. V.-SAMPATHKUMARAN, P.DWARAKADASA, E. S.: Wear, 242, 2000, p. 207.

[21] PÉREZ, M. J.-CISNEROS, M. M.-LÓPEZ, H. F.: Wear, 260, 2006, p. 879.

[22] ŠIDJANIN, L.-MIYASATO, S.: Mater. Sci. Tech., 5, 1989, p. 1200.

[23] CAI, X. L.-FENG, J.-OWEN, W. S.: Metall. Mater. Trans. A, 16, 1985, p. 1683. 